\title{
Cork oak pests: a review of insect damage and management
}

\author{
Riziero Tiberi ${ }^{1} \cdot$ Manuela Branco $^{2} \cdot$ Matteo Bracalini $^{1} \cdot$ Francesco Croci $^{1}$. \\ Tiziana Panzavolta ${ }^{1}$
}

Received: 7 July 2015 / Accepted: 10 December 2015 / Published online: 20 January 2016

(C) INRA and Springer-Verlag France 2016

\begin{abstract}
- Key message Cork oak decline is widespread in all its distribution range and seems to be triggered mainly by both mismanagement and unfavorable climatic factors. As a result, cork oak forests become susceptible to pest attack, which accelerates the onset of decline. Pest management strategies for this valuable and highly biodiverse ecosystem are examined in this review, taking into account the main insect pests and how their impact on cork oak forests is affected by climate change. While monitoring pests may
\end{abstract}

Handling Editor: Aurelien SALLE

Contribution of the co-authors Riziero Tiberi and Tiziana Panzavolta: conceived the idea, supervised literature reviewing, wrote the manuscript, and reviewed its final version.

Manuela Branco: contributed to the writing of the manuscript, the reviewing of literature, and the revision of the final draft.

Matteo Bracalini: contributed to the writing of the paper, the selection of literature, and the English revision of the manuscript.

Francesco Croci: contributed to the writing of the manuscript and the assembling of related literature. All authors have read and approved the final manuscript.

Riziero Tiberi

riziero.tiberi@unifi.it

Manuela Branco

mrbranco@isa.ulisboa.pt

Matteo Bracalini

mbracalini@unifi.it

Francesco Croci

fcroci@unifi.it

Tiziana Panzavolta

tpanzavolta@unifi.it

1 Department of Agri-Food Production and Environmental Sciences, University of Florence, via Maragliano 77, 50144 Florence, Italy

2 Centro de Estudos Florestais (CEF), Instituto Superior de Agronomia, Universidade de Lisboa, Lisbon, Portugal provide the tools to predict the transition from endemic to epidemic insect populations, forestry practices (sanitary felling), biological control, and trapping are some of the most promising measures in protecting cork oak forests.

- Context Over the last decades, cork oak (Quercus suber L.) decline has affected millions of trees throughout its distribution range. Cork oak is a typically Mediterranean species remarkably relevant for the biodiversity and landscape conservation of vast evergreen oak forests. Cork oak is also well known and highly valued for cork production. Climatic changes, management practices, and biotic factors, particularly plant pathogens and insect pests, play a decisive role in tree death and market devaluation of cork.

- Aims Here, we review the major insect pests possibly involved in cork oak decline, while discussing pest management strategies.

- Methods A survey of the current literature was performed to identify major insect pests affecting cork oak trees, as well as to establish the most promising pest management strategies under climate change.

- Results Many authors seem to agree that the decline is triggered by both anthropogenic and abiotic factors, such as the mismanagement of cork oak forests and unfavorable climate (high temperatures and droughts). Consequently, trees become susceptible to pests and pathogens, which accelerate the onset of decline.

- Conclusion Since a further increase in temperatures and droughts is expected, developing adequate management strategies to adapt cork oak trees to climate change, while simultaneously preventing and reducing insect pest attacks, is of foremost importance in the effort to conserve these unique and highly diverse ecosystems.

Keywords Quercus suber · Cork oak decline · Climate change $\cdot$ Forest management 


\section{Introduction}

Among evergreen oaks, cork oak Quercus suber L. is of particular landscape, conservation, and economic importance, due to the high biodiversity of cork oak-dominated stands, its use in agro-silvo-pastoral systems, and its exploitation for cork. Cork oak forests occur mainly in the central and western part of the Mediterranean Basin, in discontinuous areas from southern Italy to the Iberian Peninsula, and in North Africa among the Atlas Mountain forests, in Morocco, Algeria, and Tunisia in genetically differentiated populations (Magri et al. 2007) (Fig. 1). Cork oak finds optimal growing conditions in humid and sub-humid areas with at least $450 \mathrm{~mm}$ mean annual rainfall, such as in the Atlantic areas (Portugal and Morocco) of its geographical range. A unique aspect of the cork oak forest ecosystem is its continuing manipulation by humans since ancient times. In its western range, the management of these forest areas has led to low-density cork oak savannas with about 30-60 trees per ha, with a high diversity of associated plant and animal communities, and whose conservation is dependent on human mediated actions (Bugalho et al. 2011). In Spain and Portugal, for example, cork oak, together with other oak species, is part of a traditional Mediterranean silvopastoral system, which has high socio-economic importance, also providing environmental benefits (Antonietty 2013). Yet, the over-exploitation of cork oak in northwestern Africa, as well as partial abandonment in southwestern Europe, may still both compromise the sustainability of these forest areas and raise conservation concerns.

Over the last decades, cork oak decline has affected millions of trees throughout its distribution range (Luisi et al. 1993). Records from the whole cork oak distribution range highlighted the increasing occurrence of weakened cork oak trees (Sechi et al. 2002), as confirmed by a higher mean defoliation rate (Michel et al. 2014) with a resulting decrease in cork production (losses ranged from 40 to $89 \%$ ) (Sousa and Kadiri 2005). This phenomenon includes also an increase of the annual rate of clearance (from 3.9 to $4.4 \%$ per year) (Cano et al. 2003; Costa et al. 2014) and even a regression of the cork oak forests (Sedda et al. 2011).

Driving factors of tree decline are numerous, including abiotic, biotic and anthropogenic ones. Climatic anomalies, namely increasing temperatures, repeated and prolonged periods of drought (Branco and Ramos 2009), as well as recurring wildfires (Catry et al. 2014) are among the most important factors involved in this phenomenon. Anthropogenic factors, namely, incorrect management practices, which lead to soil overuse, overgrazing, and over-exploitation of trees (Branco and Ramos 2009; Pereira et al. 2012; Branco et al. 2014) are involved as well. In addition, biotic factors, particularly plant pathogens and insect pests, play a decisive role in tree death, which may be in part explained by predisposition factors induced by tree physiological stress. Indeed, several harmful insect species are increasingly more abundant and frequent in cork oak forests, contributing to the general cork oak decline and market devaluation of cork (Sousa and Kadiri 2005). Here, we review the major insect pests affecting cork oak trees, while scrutinizing their possible role in cork oak decline. Furthermore, we examine pest management strategies for this unique and highly biodiverse ecosystem and discuss how forest health is affected by climate change.

\section{Cork oak pests}

Many phytophagous insects feed frequently or occasionally on cork oak trees (Villemant and Fraval 1993a; Villemant and Fraval 1993b), though only some species attain pest status. These species can be sorted into five main feeding guilds: sap-sucking insects, gall makers, acorn feeders, defoliating insects, and bark-/wood-boring insects. Sap-sucking insects are not usually harmful to cork oaks, causing mostly aesthetic damage, such as Phylloxera quercus Boyer de Fonscolombe and Kermes vermilio Planchon, just to name a few. However, the latter species deserve more consideration as it poses as a possible vector of the pathogenic fungus Diplodia mutila $\mathrm{Fr}$. apud Mont. (Ibarra et al. 2001). Some gall makers, gall midges, and gall wasps occur on cork oaks; however, damage is almost never recorded on this plant species (Villagrán et al. 2002; Skuhravá et al. 2006; Pujade-Villar et al. 2010). As regards acorn feeders, insects that mostly feed on acorns are the weevil Curculio elephas (Gyllenhaal) (Coleoptera, Curculionidae) and moths from the genus Cydia Hübner (Lepidoptera, Tortricidae). They somewhat contribute to threatening both natural regeneration and afforestation projects in cork oak ecosystems; however, several other biotic agents play a bigger role here, like birds and mammals, affecting acorns, seedlings, and young cork oak plants (Acácio et al. 2007). Furthermore, abiotic factors, like water stress (Vaz et al. 2012), and anthropogenic factors, such as woodland multiuse and associating pastures (Branco et al. 2002; Branco and Ramos 2009), contribute to this phenomenon.

For all these reasons, sap-sucking insects, gall makers, and acorn feeders were not considered in this review. On the other hand, several defoliating insects can be particularly harmful to both young and adult trees, while some bark- and woodboring species can cause serious damage, especially to adult and senescent trees. Hence, in this review, we will focus on these two groups.

\subsection{Defoliating insects}

While a high diversity of defoliators is associated with Q. suber, as with oak species in general, only some defoliating insect species are able to cause very severe and recurring defoliations, engendering significant damage (Branco and 


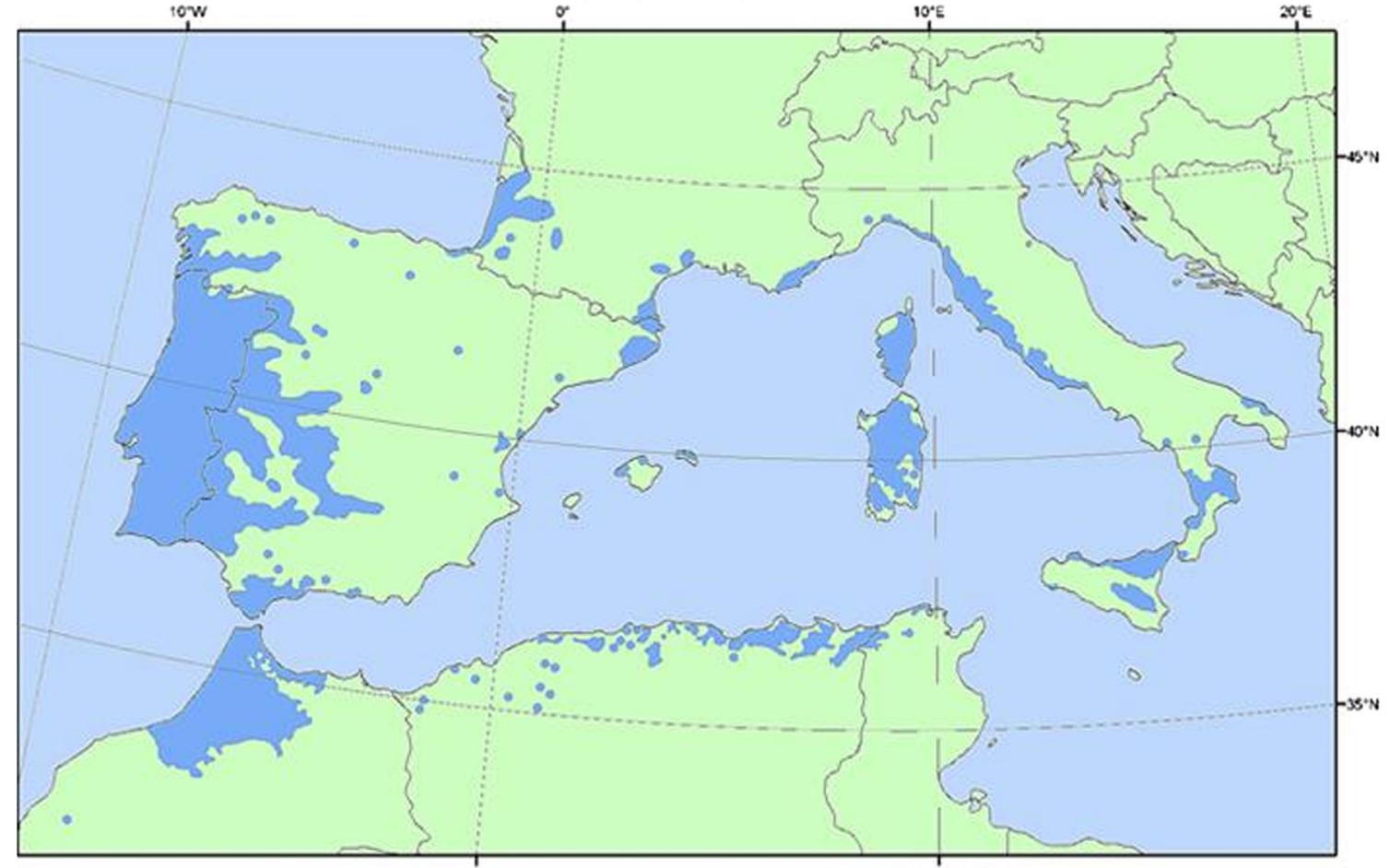

Fig. 1 Current distribution of $Q$. suber (EUFORGEN database http://www.bioversityinternational.org/networks/euforgen)

Ramos 2009). Severe damage is normally associated with outbreaks in which insect populations attain high-density levels causing extensive or even complete defoliation. Usually, these outbreaks last from 1 to 4 years. Leaf mass reduction caused by the voracious larvae may then have consequences on tree growth, affecting both height growth and radial increment, as well as cork production (Magnoler and Cambini 1970). Further defoliation causes plant physiological stress and reduced vigor, which may be long-lasting with consequences persisting over subsequent years (Tiberi et al. 1993). Indeed, trees need several years, depending on defoliation intensity, to re-establish normal growth rates (Tiberi et al. 1993). Thus, severe and repeated insect defoliations are considered a significant causal factor of oak decline, if not of oak mortality, since they further predispose trees to the attack of other organisms such as pathogens and xylophagous insects (Thomas 2008).

Among the numerous cork oak defoliating insects, moths are the most abundant and harmful. Still, there are differences across the different Mediterranean regions among the most damaging defoliator species. Some defoliating moths are reported as cork oak pests in the entire Mediterranean Basin, such as Lymantria dispar (L.) (Lepidoptera: Lymantriidae) and Tortrix viridana L. (Lepidoptera: Tortricidae) (Luciano and Prota 1995; Ben Jamâa et al. 2002; Chakali et al. 2002; Martin et al. 2002; Serrão 2002; Ouakid et al. 2005; Sousa and Kadiri 2005; Villemant 2005; Mannai et al. 2010; BouchaourDjabeur 2013). In contrast, some species are harmful only in particular regions. This is the case of Euproctis chrysorrhoea
(L.) (Lepidoptera: Lymantriidae) in Spain, Portugal (Serrão 2002; Sousa and Kadiri 2005; Ceia and Ramos 2014), Morocco (Villemant and Fraval 1993b), and Algeria (Chakali et al. 2002), as well as Malacosoma neustria (L.) (Lepidoptera: Lasiocampidae) in southern Italy (Magnoler and Cambini 1970; Luciano and Prota 1995; Verdinelli et al. 2002; Catry et al. 2012; Ceia and Ramos 2014). Finally, Periclista andrei Konow (Hymenoptera: Diprionidae) is mainly reported as a cork oak pest in Portugal (Branco and Ramos 2009).

A few other species are minor pests in restricted areas. For example, Orgyia trigotephras Boisduval (Lepidoptera: Lymantriidae) is a cork oak pest in Morocco and Algeria (Villemant and Fraval 1993a; Chakali et al. 2002), while no damage from it is reported in Europe or Tunisia, where it prefers shrubs (Ezzine et al. 2014). Although cork oak, like other evergreen oaks, has leaves all year round, most defoliator species feed on new leaves, during spring and summer.

\subsubsection{L. dispar}

The gypsy moth $L$. dispar is the major cork oak defoliator all over its geographical range. It is a univoltine species and a mid-season defoliator. During summer, females lay overwintering egg masses on host tree trunks and branches. Larval hatching is spread out over a period of more than 2 months; therefore, larval development lasts for a long period until summer (Mnara et al. 2005). Each larva completes its development in about 2 months, depending on food quality. 
For example, development rate decreases when larvae feed on older leaves, because of low nitrogen content (Schafellner et al. 2005; Kula et al. 2013), or when they feed on nonpreferential host trees and after severe defoliations (Roden and Mattson 2008).

L. dispar is well known for being polyphagous, yet, in the Mediterranean regions, cork oak and the holm oak Quercus ilex L. are its preferred host species (Villemant and Fraval 1999). Among Mediterranean oaks, cork oak also offers the best food to its larvae (Luciano et al. 1999). Plant community makeup may be a relevant factor; for instance, in Sardinia, L. dispar infestations are more frequent when cork oak occurs in pure forests than in mixed ones (Cocco et al. 2010).

L. dispar has periodic fluctuations in its population density (Luciano and Prota 1995; Cocco et al. 2010). Heavy infestations, lasting about 3 years (during which trees are almost completely defoliated), are followed by latent periods, varying from 5 to 6 years up to 10-12 years (Luciano and Prota 1995; Villemant and Fraval 1999; Martin et al. 2002; Basri et al. 2005). In Tunisia, defoliation periods of 13 consecutive years have been observed, with latent intervals of even 20-25 years (Ben Jamâa et al. 2002). During outbreaks, L. dispar can defoliate huge forest areas; for example, up to $60 \%$ of 100 ha of Sardinian cork oak forests were defoliated in a single year (Contarini et al. 2013). In conclusion, L. dispar is one of the most damaging cork oak defoliators because of multiple factors, including the severe and recurrent outbreaks, the voracity of the larvae, and the long feeding period. A single year may be enough to cause complete defoliation and induce subsequent diebacks, making this insect of utmost concern, as observed on deciduous oaks (Thomas 2008).

\subsubsection{T. viridana}

The green oak leaf roller $T$. viridana is one of the main oak defoliators in the Palearctic region (Ivashov et al. 2002). In Mediterranean areas, $T$. viridana causes heavy defoliations to cork oaks (Villemant and Fraval 1993b; Mannai et al. 2010; Antonietty 2013). In Algeria, heavy infestations, lasting about 2 to 3 years, are followed by latent 5 -year intervals (Chakali et al. 2002), while in Sardinia, outbreaks occur every 6 to 10 years and last 3 to 5 years (Luciano and Prota 1995).

Like $L$. dispar, $T$. viridana has one generation per year, though it is an early-season defoliator. Larvae hatch at budburst and then first instar larvae start to feed inside the buds. After this stage, larvae feed on the young leaves, which provide a more nutritious food (Feeny 1970; Ivashov et al. 2002). In fact, older Quercus leaves have both a lower content in amino acids and water and a higher content in phenols (Feeny 1970). Although newly hatched larvae can resist starvation for up to 10 days, the fitness of this insect species relies on phenological synchronization with the host plant (Ivashov et al. 2002). Therefore, egg hatching is well synchronized with host bud break, which varies according to the host species, giving rise to host adaptation (Du Merle 1999). Thus, distinct subpopulations of the moth may occur in mixed oak forests, displaying different development length depending on the host plant bud break time (Ivashov et al. 2002; Serra and Lentini 2012; Schroeder and Tiberi 2014). Antonietty (2013) recently confirmed this by finding a positive correlation between leaf development and larval development.

\subsubsection{E. chrysorrhoea}

The brown-tail moth, E. chrysorrhoea is the only late-season defoliator, among the species here considered. This insect species is polyphagous; it feeds on both broadleaf trees and shrubs (Frago et al. 2010). It occurs frequently on cork oak, but seldom causing serious damage. This insect species has a long-lasting larval stage of up to 10 months. In autumn, the larvae weave an overwintering nest, made up of leaves tied together by silk threads, and which is usually located on the outer portion of the tree crown.

Other Mediterranean defoliator species similarly overwinter as larvae, such as the pine processionary moth Thaumetopoea pityocampa (Denis \& Schiffermüller). However, in contrast to the pine defoliator, E. chrysorrhoea larval development during autumn-winter greatly depends on the presence of leaves on the host plant. On deciduous plants, larval winter diapause is longer, while on evergreen hosts, like for example the strawberry tree Arbutus unedo L., larvae feed during winter as long as the weather conditions allow it (Frago et al. 2010). The opportunity to eat for a longer period leads to increased larval size (Frago et al. 2010) and probably also reduces larval mortality, as verified for other overwintering lepidopteran larvae (Battisti et al. 2005). Similarly, being the cork oak an evergreen tree, we assume that E. chrysorrhoea larvae may benefit of the same advantages as on the strawberry tree. Differences in phenology according to host species may also cause limited gene flow between populations, which may explain the existence of host-races within this species (Marques et al. 2014).

E. chrysorrhoea is dangerous for human health and warmblooded animals in general, due to urticating larval hairs, which increase with larval growth (Werno and Lamy 1994). Thus, public health concern is most elevated during May and June, when this species reaches larval maturity. In this period, in urban and suburban areas, as well as in cork oak plantations, cases of skin irritation and breathing difficulties may be frequent and sometimes severe, especially during heavy E. chrysorrhoea infestations.

\subsubsection{M. neustria}

M. neustria is an univoltine species which, similarly to L. dispar, is a mid-season defoliator. M. neustria often shares 
host plants with $L$. dispar for larval development; however, its populations are less numerous and confined to limited areas, if not to individual oak trees. The outbreaks typically fluctuate every 8 to 9 years (Luciano and Prota 1995), but damage may be extended for several subsequent years due to consequent losses in both cork and wood production (Verdinelli and Sanna-Passino 2003). M. neustria is a polyphagous species, but among Quercus species, the holm oak Q. ilex seems to be its preferred host.

\subsubsection{P. andrei}

P. andrei is a sawfly which is particularly active in the western distribution of the cork oak, namely, in Portugal, where it is one of the main cork oak defoliators (Branco and Ramos 2009; Pereira et al. 2012). Reproduction is mostly parthenogenic. After hatching, the larvae start feeding on the new foliage; development lasts about 2 to 3 weeks, after which the larvae descend to the soil to pupate. A prolonged diapause of 1 to 3 years may then occur. Defoliation may be intense, leading to complete defoliation in some areas.

\subsubsection{Minor defoliators in restricted areas}

As for the other defoliators that cause more localized damage, we report three species with a quite early behavior. $O$. trigotephras, a xerothermophilic species, feeds on evergreen oaks and shrubs (Ezzine et al. 2014; Ezzine et al. 2015). Several sub-species are known, Orgyia trigotephras anceps Oberthür being the most cited in Algeria and Morocco for its damage to cork oaks (Villemant and Fraval 1993b; Chakali et al. 2002). Furthermore, two species belonging to the Catocala genus, Catocala nymphaea (Esper) (Lepidoptera: Noctuidae) and Catocala nymphagoga (Esper) (Lepidoptera: Noctuidae), are reported, mainly on holm oak and cork oak in North Africa (Villemant and Fraval 1993b; Chakali et al. 2002).

\subsection{Bark- and wood-boring insects}

Insects associated with bark and wood play a major role in oak decline in Europe (Thomas 2008; Inácio et al. 2011). They dig galleries under the bark and into the wood of weakened trees, frequently causing tree death (Sallé et al. 2014). In addition, they play a major role in pathogenic fungal spread (Sousa and Inácio 2005; Henriques et al. 2006; Belhoucine et al. 2011). Some xylophagous species in particular are associated with cork oak decline (Sallé et al. 2014). Usually, these are considered "secondary" species, attacking stressed and weakened plants (Sallé et al. 2014), although in some cases they can be very dangerous even for healthier trees (Martín et al. 2005). Physiological stress by abiotic causes (Du Merle and Attié 1992; Cao and Luciano 2005) and insect defoliation (Sousa and Kadiri 2005) are two main predisposing factors. In addition, the cork extraction process and pruning have been shown to be stress factors in cork oaks, thus favoring the outbreaks of these insects (Cao and Luciano 2005; López-Pantoja et al. 2011).

The main xylophagous insects harmful to the cork oak belong to the Coleoptera order: specifically the Cerambycidae, Buprestidae, and Curculionidae families (Branco and Ramos 2009; Sallé et al. 2014). Platypus cylindrus (Fabricius) (Coleoptera: Curculionidae: Platypodinae), as well as the long-horned beetles Cerambyx cerdo L., Cerambyx cerdo mirbeckii (Lucas), Cerambyx welensii (Kuster), and Prinobius myardi Mulsant, is the species most often associated with cork oak decline (Thomas 2008; Inácio et al. 2011; Sallé et al. 2014). Furthermore, the buprestids Coraebus florentinus (Herbst) and Coraebus undatus (Fabricius) (Branco and Ramos 2009; Gallardo et al. 2012; Jiménez et al. 2012) are considered significant for the damage they cause, especially in the Iberian Peninsula. Particularly C. undatus, whose galleries in the phellogen, the tissue responsible for cork production, causes the depreciation of cork planks (Du Merle and Attié 1992; Jiménez et al. 2012).

\subsubsection{P. cylindrus}

P. cylindrus is an ambrosia beetle characterized by a xylomycetophagous behavior. Its adults dig tunnels in the wood of the host plants, while injecting fungal ectosymbionts, such as Raffaellea sp., whose mycelium is fed on by both adults and larvae. On the contrary, the other reported species feed on subcortical layers and/or the host plant's wood only during their larval stage, while adults feed on foliage, nectar, or liquids exudating from the bark of trunks and branches. Additionally, P. cylindrus helps the spread of many other fungi, some of which are phytopathogenic, such as the agent of cork oak charcoal canker, Biscogniauxia mediterranea (De Not) (Inácio et al. 2011). These associations are particularly harmful, as these fungi further contribute to cork oak decline (Sousa and Inácio 2005; Henriques et al. 2006). In the Iberian Peninsula, the attacks of $P$. cylindrus are found particularly dangerous, causing tree death in 1 to 3 years, not only on weakened or stressed plants but also on apparently healthy ones, as recently reported by Inácio et al. (2011) and Bellahirech et al. (2014). The same occurred in Morocco and Algeria, while in Tunisia, the insect maintains a secondary pest status (Bellahirech et al. 2015). The meaning of this different aggressiveness of P. cylindrus' populations is not yet understood; in fact, Bellahirech et al. (2015) could not explain it as they did not find differences in the beetle genetic features or in morphological traits of its mycangial pits. 


\subsubsection{C. cerdo}

C. cerdo, being usually associated to aging or dead trees, is considered a vulnerable and protected species in Europe; however, wounds from inappropriate pruning or cork stripping may turn this species into a serious pest, damaging not only old trees but also young ones (Martín et al. 2005). Its females lay eggs in bark cracks (El Antry 1999); thus, they are favored by the aforementioned wounds (López-Pantoja et al. 2011), as well as by the resulting physiological stress (Martín et al. 2005). Furthermore, exit holes produced by the long-horned beetle provide an entryway for fungal infection by B. mediterranea (Martín et al. 2005). High damage of the sub-species C. cerdo mirbeckii is reported for Morocco (El Antry 1999) and Algeria (Bouhraoua et al. 2002; Chakali et al. 2002).

\subsubsection{C. welensii and P. myardi}

Like C. cerdo, these two beetles are, in some cases, also considered able to attack healthy plants. For example, attacks by $C$. welensii and $P$. myardi against young plants in fine vegetative condition are becoming more frequent (Torres-Vila et al. 2012; Sallé et al. 2014). In addition, they may also facilitate the entry of pathogens in trees, through their emergence holes (Martín et al. 2005). However, these long-horned beetles are mostly known to colonize trees that are already showing symptoms of some physiological decline (Torres-Vila et al. 2012).

\subsubsection{C. florentinus and C. undatus}

The two buprestids may also be associated with plant pathogenic fungi. In particular, the association between C. florentinus and the fungus D. mutila has been suggested, as they are frequently observed together on the same plants and on the same samples of wood (Tiberi et al. 2002). C. florentinus attacks the lignified parts of the canopy, i.e., branches up to 8 -cm wide, ultimately killing them. Frequent occurrences are recorded for the holm oak and for the cork oak, although tree damage is not severe as it is confined to branches. On the other hand, C. undatus deserves much more consideration, as it depreciates considerably the value of cork, as well as reducing its production (Gallardo et al. 2012; Jiménez et al. 2012). Its larvae dig long, sinuous tunnels winding between the wood and bark of living plants, both on the trunk and main branches. Such tunnels, which after a short time assume a blackish color, negatively affect the production of cork and hinder the cork removal process (Evans et al. 2004). In addition, woodpeckers feeding on $C$. undatus larvae along their galleries inflict further cork devaluation by opening holes when searching for larvae. Last but not least, the extraction of cork itself affects tree susceptibility to beetle attack, as it is positively correlated to the number of larval galleries (Jiménez et al. 2012).

Other insects can cause damage to cork production, while not being harmful to the plant itself. For instance, some species of ants do not feed on the plant tissues, but find refuge in it by building nests in the thickness of the bark (Verdinelli et al. 2012). This type of damage is reported both in Europe (Loi et al. 2012; Verdinelli et al. 2012) and in North Africa (Bouchaour-Djabeur 2013); the most common ant species being Crematogaster scutellaris Olivier (Hymenoptera, Formicidae) and Lasius brunneus (Latreille) (Hymenoptera, Formicidae) (Loi et al. 2012). These species cause considerable damage to cork production as ant nests depreciate its value as well as hindering the extraction process (Verdinelli et al. 2012).

\section{Pest management of cork oak forests}

\subsection{Monitoring of pests}

One of the problems in managing insect pests in cork oak forests is the difficulty in predicting their outbreaks. Natural enemies, climate, as well as plant quality have all been proposed as factors regulating forest defoliator demographics (Berryman 1996; Simchuk et al. 1999). Still, the weight of each factor is not easily determined, and difficulties often arise regarding the interpretation of the key ecological factors involved (Villemant and Fraval 1999). Thus, appropriate and reliable models for predicting the transition from endemic to epidemic of a given pest population are still lacking.

However, some biological parameters may offer indications of the population density of some lepidopteran defoliators. Useful results were attained, for example, considering the average fertility of female gypsy moths to anticipate population outbreaks. This can be done either by weighing samples of egg masses (Bariselli et al. 1994) or by simply counting the number of egg masses present in a sample area (Liebhold et al. 1995; Luciano and Lentini 2012). For M. neustria, counting egg masses on a sample of twigs has proven useful for estimating its population density (Verdinelli et al. 2002). However, in the case of species that lay eggs in small cluster, like T. viridana, counting eggs is a less reliable or feasible method. For several species, the sex pheromone is not only known but also commercially available in dispensers, offering new opportunities for monitoring populations (Jacobson et al. 1960; Arn et al. 1979). Experiments carried out in the cork oak forests of Sardinia showed an interesting correlation between the leaf roller catches in pheromone traps and the extent of infestation (Gilioli et al. 1999).

However, some authors debate on the reliability of pheromone traps for population assessment of some moths, suggesting the integration of other measures. In fact, Liebhold et al. 
(1995) did not observe a correlation between trap catches and L. dispar infestations. Similarly, Antonietty (2013) did not find a reliable correlation between the number of trapped $T$. viridana adults and the number of collected larvae, in contrast to the observations by Gilioli et al. (1999). Thus, Antonietty (2013) suggested integrating trapping data with information from larval samples, also devising an easy method to determine the phenological phase of both plant and pest, by counting the number of buds, shoots, and catkins. Finally, for species causing complete defoliation during mass outbreaks, like $T$. viridana, intraspecific competition and density-dependent variation in population growth rate may have a major role in population dynamics (Kapeller 2009). Thus, population simulation models may be useful tools for land managers (Duning et al. 1995), as recommended by Kapeller (2009).

For other groups of insects, such as xylophagous pests, assessing population densities is far more difficult; in this case, signs on the attacked trees may be taken into account. Quantifying the level of C. undatus infestation in a cork forest, for example, without first removing the bark off the trees, is currently impossible (Gallardo et al. 2012). However, other parameters provide information on the degree of infestation of this species. For example, on most of the attacked plants, leaking phloem sap from the tunnels dug by the larvae results in white-yellowish chlorotic spots, visible on the bark (Gallardo et al. 2012). The population dynamics of some wood-boring pests can also be assessed by counting the emergence holes per unit of bark surface, as well as the points of reproductive settlement, repeating observations for subsequent pest generations.

For a few xylophagous species, trap devices can be used. Purple prism traps baited with host plant volatiles were proposed for monitoring C. undatus (Fürstenau et al. 2014). Furthermore, laboratory and field studies recently showed a high sensitivity for P. myardi, C. welensii, and C. florentinus to plant volatiles, suggesting a possible use of these compounds in pest monitoring and control (Sánchez-Osorio et al. 2007; Sánchez-Osorio et al. 2009; Fürstenau et al. 2012; Sánchez-Osorio et al. 2015a; Sánchez-Osorio et al. 2015b). However, though using plant kairomone traps to estimate the population level may be a reliable method for some xylophagous pests, it is not the case for most of them (Sallé et al. 2014). For example, differences in trap catches of C. welensii in two different areas in Spain did not reflect differences in population size (Sánchez-Osorio et al. 2015b). For this species, the mark-recapture method using traps baited with food-related attractants seems to be more effective to assess adult population size, though it is more timeconsuming (Torres-Vila et al. 2012; Torres-Vila et al. 2013). For some beetle species, as in the case of $P$. cylindrus (Algarvio et al. 2002), aggregation pheromones have been identified. They may be promising tools for estimating the population density of this insect pest; in fact, being more specific, aggregation pheromones are usually more reliable, while having a lower impact on non-target species. In conclusion, trap catches can be informative about a given defoliator or wood-boring pest; however, the resulting population density assessment may sometimes be unreliable and often time-consuming. Consequently, further research is needed to develop reliable monitoring methods for these important cork oak pests.

\subsection{Pest control}

Forestry practices are usually recommended for the prevention and the control of forest pests, especially wood-boring species (Jactel et al. 2009). For example, sanitary felling and removal of trees (or parts of trees) which have been damaged by abiotic or biotic factors, as well as thinning practices which favor the most vigorous trees, may restrain xylophagous insect infestations (Muzika et al. 2000; Thomas et al. 2002; Cárdenas and Gallardo 2012). In fact, such practices reduce the availability of trees suitable for secondary species associated with weakened plants. Other deterrent measures include chemical treatments to the tree trunks after the removal of the cork, in order to prevent attacks by xylophagous insects (Cao and Luciano 2005) and pathogens (Luque et al. 2008). Furthermore, pruning wounds can lead to infections by pathogens or attack by pests (Martín et al. 2005; Jactel et al. 2009). Considering that pruning of cork oak is a traditional exploitation of some open cork oak woodlands and is usually very intensive (Cañellas and Montero 2002), protectants should be used to prevent damages. Finally, some precautions in managing cork oak forests may be useful to prevent the onset of decline. For example, refraining from collecting cork in the years of total defoliation caused by moths, or in years of severe drought, is highly recommended (Cao and Luciano 2005). Although there are doubts about the effectiveness of simple forest management in the control of wood-boring pests (Sallé et al. 2014), in many cases, it is the only measure of containment used (Evans et al. 2004).

Among direct control methods, those based on biological criteria are the most promising and safest. For the control of cork oak lepidopteran defoliators, Bacillus thuringiensis Berliner var. kurstaki (Btk) is one of the most used biological control agents, both in Europe and in North Africa. However, the effectiveness of Btk is controversial. While in Sardinia, for example, the results of Btk treatments were evaluated over a period of 10 years and were considered satisfactory (Luciano and Lentini 2012), on the other hand, Btk has been shown to be easily washed off by rain, reducing its efficacy (Serrão 2002). One advantage of Btk is its low persistency, which results in its reduced accumulation in the soil (Petrucci et al. 2012), but, on the other hand, this can affect the treatment's usefulness. In fact, after treatment, once all trees have been 
defoliated, the larvae simply migrate from the neighboring non-treated areas to the treated, yet no longer effective, Btktreated trees (Martin et al. 2002). For the same reason, the remarkable temporal staggering in the hatching of some species' larvae, such as $L$. dispar, causes difficulties in planning treatments. Furthermore, the use of Btk is controversial because of its non-specificity and, therefore, its potential collateral effects on non-target lepidopteran species (Contarini et al. 2013).

For all these reasons, the gypsy moth nucleopolyhedrovirus is sometimes preferred to control $L$. dispar, instead of Btk (Hajek and Tobin 2010). This virus is highly specific, effective only against the intended target, and it is used in the USA even in areas where rare or endangered species of moths are present (Hajek and Tobin 2010). Since the 1970s, this virus has been introduced and tested in North Africa and in Italy, with good results, although more studies are still needed to determine its effectiveness in the field (Cerboneschi 2005). In addition, large-scale production of this virus is not simple, as it involves in vivo techniques (Hajek and Tobin 2010). In any case, the use of this product may prove to be promising in the Mediterranean countries where $L$. dispar causes considerable loss to cork production, especially where the biocenosis needs to be protected as much as possible.

Studies on natural enemies of cork oak pests cover only few pest species and their results are debatable. For instance, the biological control agent Ooencyrtus kuvanae (Howard) (Hymenoptera, Encyrtidae), an egg parasitoid native to Japan, was introduced in North America, Europe, and North Africa against $L$. dispar. The results were variable and dependent on the density of the host (Brown 1984). In Tunisia, the parasitoid was not able to control the outbreaks of its host; however, other natural limiting factors are sometimes enough to contain the moth populations (Ben Jamâa et al. 2002). Another natural enemy of the gypsy moth is the gregarious, braconid species Glyptapanteles liparidis (Bouché) (Hymenoptera, Braconidae). This species, whose behavior includes the injection, during oviposition, of a symbiotic virus and venom into the host larva (Schafellner et al. 2004), has a main role as a larval parasitoid in Austria (Schafellner et al. 2005).

Sex and aggregation pheromones are also promising for pest control strategies. Sex pheromones, successfully used to monitor lepidopteran defoliators, may be also used as direct control tools, e.g., through sexual confusion (Tiberi et al. 1988). The mating disruption technique may be used to control gypsy moth (Thorpe et al. 2006). In fact, aerial or ground applications have proved successful in reducing isolated populations or low-density populations on wide areas (Thorpe et al. 2006). As regards beetles, mass trapping trials of P. cylindrus using pheromone traps in Portugal have proved effective in reducing its population levels (Bonifácio, pers. observ.). This control technique is considered the best option to control the ambrosia beetle; in fact, it acts preventively, it is specific, and it is environmentally friendly (Henriques et al. 2010).

To control beetle pests, good results have been achieved also using traps baited with attractants. For example, food attractants (Torres-Vila et al. 2012) and synthetic blends mimicking fermentation odors (Sánchez-Osorio et al. 2015b) have been effectively used for the mass capture of $C$. welensii adults, especially before they could mate (Torres-Vila et al. 2012). Furthermore, traps baited with plant semiochemicals have been proposed to control C. cerdo (González et al. 2013). In general, attractants used to capture or prevent mating of pests may be a key factor in integrated pest management to control their population density.

The most promising strategies for future pest management are those integrating several control methods under an integrated pest management strategy. In particular, to control lepidopteran defoliators, Btk treatments could be combined with the artificial enhancement of parasitoids; Btk would ensure an effective short-term containment, allowing the parasitoids to respond to their host's population density. Significant results could be also achieved by combining sex attractants with the artificial enhancement of natural enemies in the environment, as well as by using aggregation pheromones together with the timely removal of plants attacked by xylophagous pests (Tiberi and Covassi 1994).

\section{Effect of climate change on cork oak pests}

Over the last decades, many studies on climate trends have been carried out and results demonstrate that the ongoing climate change concerns large parts of our planet, affecting both animals and plants (Coley 1998; Cannon 1998; IPCC 2014; Ockendon et al. 2014). Many plant and animal species might be unable to adapt locally or move fast enough to counterbalance negative effects of climate changes (IPCC 2014). As regards insects, warmer temperatures might affect directly their population dynamics through changes on survival, generation time, fecundity, and dispersal (Stange and Ayres 2010). Furthermore, climate change can affect phytophagous insects also indirectly, by modifying host resistance and quality (Mattson and Haack 1987; Allen et al. 2010; Choi 2011; Sallé et al. 2014), as well as by affecting their natural enemies (Stireman et al. 2005; Hance et al. 2007; Klapwijk et al. 2012). However, predator and parasitoid insects are supposedly more susceptible to environmental changes than herbivorous ones, since they also depend on their hosts' resilience (Hance et al. 2007). Anyway, some plant and animal species may react to this phenomenon, showing a response to climate change, which may lead to adaptation and mitigation of its effects (Skelly et al. 2007). 
Climate change causes increasing droughts in the northern hemisphere, particularly in the Mediterranean climates, with resulting damage to plants. A 20-year study (1987-2007) conducted in the Iberian Peninsula showed an increase in the indices of tree defoliation due to intensifying water deficit, especially in the more arid areas (Carnicer et al. 2011). An increasing number of studies also show a link between drought and cork growth reduction (Caritat et al. 2000), as well as tree mortality (Allen et al. 2010; Carnicer et al. 2011). Despite being a species resistant to drought due to its deep root system and to the water lift adaptation mechanism (Kurz-Besson et al. 2006), the cork oak can be affected by this phenomenon (David et al. 2007; Grant et al. 2010). Reduction of tree resistance to biotic factors, especially xylophagous insects, due to water stress is a well-known mechanism (Allen et al. 2010; Choi 2011; Sallé et al. 2014). After multiple years of drought, in particular if site conditions are not ideal, cork oaks may undergo extensive die-offs, often associated with insect pest infestations. In fact, during protracted drought, stomatal closure leads to poorer photosynthesis, as well as to a lower tissue water potential, thus causing carbon starvation and possibly a decrease in production and translocation of secondary metabolites, used by the plant as defense against insect pests and pathogens (Allen et al. 2010). An additional effect of the water content reduction is the consequent higher concentration of nutrients in plant tissues, which make them more nutritious for several insect species (Mattson and Haack 1987).

Insects are differently affected by stress-induced plant changes accordingly with the plant tissues they feed on and with their feeding method (Koricheva et al. 1998; Huberty and Denno 2004). Sap-sucking insects may be positively affected by a stress-induced increase in soluble nitrogen, but only if the water stress is intermittent, because they need turgid plants to efficiently ingest this nutrient (Huberty and Denno 2004). Defoliating insects, particularly free-living ones, cannot take advantage from increased nitrogen, because water stress often increases also allelochemical levels, mainly in leaf tissues; thus, they are negatively affected (Inbar et al. 2001). Illustratively, in Portugal, recent outbreaks of $L$. dispar were more confined (Serrão 2002) and lasted fewer years in comparison with the first half of the twentieth century (Nogueira 1968), which is in accordance to this hypothesis. Similarly, gall formers are not favored by water stress too, because gall formation is possible only on vigorous, expanding plants (Huberty and Denno 2004). As regards insects adapted to exploit stressed or senescent plants, like bark- and woodboring insects, clearly they are positively affected. These secondary species may take advantage of greater quantities of stressed plants, suitable for colonization, allowing further build-ups of their populations. Outbreaks would then make these species particularly dangerous, even for healthier trees. This is confirmed by the ability of some wood-boring species harmful to the cork oak in attacking apparently healthy plants, as in the case of $P$. cylindrus, Cerambyx spp., Coraebus spp., and P. myardi (Martín et al. 2005; Allen et al. 2010; Inácio et al. 2011; Torres-Vila et al. 2012; Sallé et al. 2014).

The increase in average winter temperatures recorded since the second half of the 1900s (Kumar et al. 2005) is also central to pest populations, especially considering this trend is likely to continue in future years. The recurrence of milder winters may favor population outbreaks of several insect pests and plant pathogens due to reduced winter mortality. Temperature can also indirectly affect insect mortality, as favorable temperatures may allow overwintering larvae to feed during the winter months, thereby increasing their survival (Battisti et al. 2005) and reducing development time (Berger et al. 2008). As far as cork oak is concerned, if we take as an example E. chrysorrhoea, whose overwintering larvae would benefit from warmer winter weather conditions, climate change would result in higher populations, making it more dangerous for cork oak in the near future. Similarly, lower winter temperature have a limiting effect on the survival of Phytophthora cinnamomi Rands (Brasier and Scott 1994; Bergot et al. 2004), one of the most devastating forest pathogens, as well as on L. dispar egg survival at the northern margin of its expanded range (Nealis et al. 1999). Due to global warming, the survival of these species during winter is supposed to increase, leading to their range expansion (Bergot et al. 2004).

Higher spring and summer temperatures may favor thermophilic insect species, while negatively affecting the cork oak (Correia et al. 2014). In such a context, some cork oak pests would find optimal conditions for their development, both in terms of thermal needs and temperature-driven effects on their host plants. For example, the larvae of $C$. florentinus are favored by temperatures above $28^{\circ} \mathrm{C}$, although their optimum could be even higher (Cárdenas and Gallardo 2012). Consequently, they would be boosted by a rise in temperatures, as confirmed by the fact that this species has recently been expanding progressively towards northern latitudes (Moraal and Jagers op Akkerhuis 2011; Buse et al. 2013). Other wood-boring insects harmful to the cork oaks, e.g., C. cerdo, are thermophilic species (Sallé et al. 2014); thus, they may shift or enlarge their geographic ranges in response to climate change, as it was observed for many other animals (IPCC 2014). This is particularly true for C. cerdo mirbeckii, which is currently present only in the southern part of the cork oak range. Furthermore, these secondary insects are indirectly favored by the physiological effects caused by high temperatures on cork oak, which are similar to those occurring in senescent tissues (Correia et al. 2014).

Many species have shown shifting phenology in response to warming trends; however, phytophagous insects and their host plants may react differently (Singer and Parmesan 2010). A warmer spring, which is likely to cause a premature cork 
oak budburst (Pinto et al. 2011), might affect moths strictly synchronized with their host, like T. viridana. A plausible consequence may be the phenological asynchrony between the insect and its host, as they show different magnitudes of response to warming trends (Singer and Parmesan 2010).

Finally, increasing droughts and rising temperatures may lead to an increased risk of fire (Aronson et al. 2009). This hypothesis is supported by the more frequent occurrence of wildfires during the last decades in the Mediterranean Basin (Catry et al. 2014). Recurring wildfires, together with drought and other stresses, may negatively affect post-fire survival of trees (Aronson et al. 2009). In addition, the outbreaks of wood-boring insects, especially beetles, following the fires may further affect cork oak stands, as recorded in Portugal by Catry et al. (2014).

\section{Conclusion}

The widespread decline affecting the cork oak seems to be governed by multiple factors. Many authors seem to agree that the decline is triggered by both anthropogenic and abiotic factors, such as the mismanagement of cork oak forests and unfavorable climatic factors (Sousa and Kadiri 2005; Thomas 2008; Branco and Ramos 2009). Consequently, trees become susceptible to pest and pathogen attacks, which accelerate the onset of decline. Insect population density is linked to the climate, either directly or indirectly, such as through plant physiology; since a further increase in temperatures and droughts is expected, this matter is even of more of concern. Thus, developing adequate management strategies to adapt cork oak trees to climate change (Vericat et al. 2012), while simultaneously preventing and reducing pest populations, is of foremost importance in the effort to conserve these unique and highly diverse ecosystems. Simulation models may be particularly useful in predicting population response to environmental changes; thus, they could help to develop forest management measures to compensate for climate change damages (Duning et al. 1995).

\section{References}

Acácio V, Holmgren M, Jansen PA, Schrotter O (2007) Multiple recruitment limitation causes arrested succession in Mediterranean cork oak systems. Ecosystems 10:1220-1230. doi:10.1007/s10021-0079089-9

Algarvio R, Teixeira C, Barata E, Pickett J, Casas Novas P, Figueiredo D (2002) Identification of a putative aggregation pheromone from males Platypus cylindrus (Coleoptera: Platypodidae). Proceedings of the International Society of Chemical Ecology 19th annual meeting. University of Hamburg, Hamburg, p 152
Allen CD, Macalady AK, Chenchouni H, Bachelet D, McDowell N, Vennetier M, Kitzberger T, Rigling A, Breshears DD, Hogg EHT, Gonzalez P, Fensham R, Zhang Z, Jn C, Demidova N, Lim JH, Allard G, Running SW, Semerci A, Cobb N (2010) A global overview of drought and heat-induced tree mortality reveals emerging climate change risks for forests. For Ecol Manage 259:660-684. doi: 10.1016/j.foreco.2009.09.001

Antonietty CA (2013) Diseño de un plan de manejo integrado para Tortrix viridana L. (Lepidoptera: Tortricidae). Docthoral Thesis, Universidad de Sevilla

Arn H, Priesner E, Bogenschütz H, Buser HR, Struble DL, Rauscher S, Voerman S (1979) Sex pheromone of Tortrix viridana: (Z)-11tetradecenyl acetate as the main component. Zeitschrift für Naturforsch C 34:1281-1284. doi:10.1515/znc-1979-1237

Aronson J, Pereira JS, Pausas JG (eds) (2009) Cork oak woodlands on the edge. Island Press, Washington

Bariselli M, Nanni C, Boselli M (1994) Prime indagini sulle ovideposizioni di Lymantria dispar L. come elemento di previsione delle infestazioni in alcune aree dell'Appennino bolognese. Proceedings of the XVII Congresso nazionale Italiano di Entomologia. Udine, pp 755-758

Basri E, El Antry S, Atay-Kadiri Z (2005) Cartographie des infestations de Lymantria dispar et superficies traitées contre le ravageur entre 1990 et 2004 en subéraie de la Mamora (Maroc). IOBC/wprs Bull 28:163-168

Battisti A, Stastny M, Netherer S, Robinet C, Schopf A, Roques A, Larsson S, Netherer S (2005) Expansion of geographic range in the pine processionary moth caused by increased winter temperatures. Ecol Appl 15:2084-2096. doi:10.1890/04-1903

Belhoucine L, Bouhraoua RT, Dahane B, Pujade-Villar J (2011) Aperçu biologique du Platypus cylindrus (Fabricius, 1792) (Coleoptera, Curculionidae : Platypodinae) dans les galeries du bois de chêneliège (Quercus suber L.). Orsis Org i Sist 25:105-120

Bellahirech A, Inácio ML, Bonifácio L, Nóbrega F (2014) Comparison of fungi associated with Platypus cylindrus F. (Coleoptera: Platypodidae) in Tunisian and Portuguese cork oak stands. IOBC/wprs Bull 101:149-156

Bellahirech A, Inácio ML, Nóbrega F, Henriques J, Bonifácio L, Sousa E, Ben Jamâa ML (2015) Can behavioural differences in Platypus cylindrus (Coleoptera: Platypodinae) from Portugal and Tunisia be explained by genetic and morphological traits? Bull Entomol Res 18. doi: $10.1017 / \mathrm{S} 0007485315000437$

Ben Jamâa ML, M'nara S, Villemant C, Khaldi A (2002) Lymantria dispar L. (Lepidoptera, Lymantriidae) en Tunisie: état actuel des connaissances et perspectives de recherche. IOBC/wprs Bull 25: $101-108$

Berger D, Walters R, Gotthard K (2008) What limits insect fecundity? Body size- and temperature-dependent egg maturation and oviposition in a butterfly. Funct Ecol 22:523-529. doi:10.1111/j.13652435.2008.01392.x

Bergot M, Cloppet E, Perarnaud V, Perarnaud V, Deque M, Marcais B, Desprez-Loustau ML (2004) Simulation of potential range expansion of oak disease caused by Phytophthora cinnamomi under climate change. Glob Chang Biol 10:1539-1552. doi:10.1111/j.13652486.2004.00824.x

Berryman AA (1996) What causes population cycles of forest Lepidoptera? Trends Ecol Evol 11:28-32. doi:10.1016/01695347(96)81066-4

Bouchaour-Djabeur S (2013) Les insectes ravageurs du chêne liège au Nord-Ouest Algérien. Geo Eco Trop 36:175-184

Bouhraoua RT, Villemant C, Kheli MA, Bouchaour S (2002) Situation sanitaire de quelques subéraies de l'Ouest Algérien : impact des xylophages. IOBC/wprs Bull 25:85-92

Branco M, Ramos P (2009) Coping with pests and diseases. In: Aronson J, Pereira JS, Pausas JG (eds) Cork oak woodlands on the edge: 
ecology, adaptive management, and restoration. Island Press, Washington, pp 103-111

Branco M, Branco C, Merouani H, Almeida MH (2002) Germination success, survival and seedling vigour of Quercus suber acorns in relation to insect damage. For Ecol Manage 166:159-164. doi:10. 1016/S0378-1127(01)00669-7

Branco M, Bragança H, Sousa E, Phillips AJ (2014) Pests and diseases in Portuguese forestry: current and new threats. In: Reboredo F (ed) Forest context and policies in Portugal. Springer International Publishing, pp 117-154

Brasier C, Scott K (1994) European oak decline and global warming: a theoretical assessment with special reference to the activity of Phytophthora cinnamomi. Bull OEPP/EPPO 24:221-232. doi:10. 1017/CBO9781107415324.004

Brown MW (1984) Literature review of Ooencyrtus kuvanae (Hym.: Encyrtidae), an egg parasite of Lymantria dispar (Lep: Lymantriidae). Entomophaga 29:249-265. doi:10.1007/ BF02372112

Bugalho MN, Caldeira MC, Pereira JS, Aronson J, Pausas JG (2011) Mediterranean cork oak savannas require human use to sustain biodiversity and ecosystem services. Front Ecol Environ 9:278-286. doi:10.1890/100084

Buse J, Griebeler EM, Niehuis M (2013) Rising temperatures explain past immigration of the thermophilic oak-inhabiting beetle Coraebus florentinus (Coleoptera: Buprestidae) in South-West Germany. Biodivers Conserv 22:1115-1131. doi:10.1007/s10531-012-0395-y

Cañellas I, Montero G (2002) The influence of cork oak pruning on the yield and growth of cork. Ann For Sci 59:753-760. doi:10.1051/ forest:2002061

Cannon RJC (1998) The implications of predicted climate change for insect pests in the UK, with emphasis on non-indigenous species. Glob Chang Biol 4:785-796. doi:10.1046/j.1365-2486.1998.00190.

Cano F, Navarro RM, García Ferrer A (2003) Evolución de la cubierta de alcornoque en un monte afectado por Seca (La Alcaidesa-Cádiz) mediante una secuencia de fotografías aéreas. Ecología 17:131-144

Cao OV, Luciano P (2005) Severe infestations of Platypus cylindrus Fabricius (Coleoptera Platypodidae) in Sardinian cork oak forests. IOBC/wprs Bull 28:145-146

Cárdenas AM, Gallardo P (2012) The effect of temperature on the preimaginal development of the jewel beetle, Coraebus florentinus (Coleoptera: Buprestidae). Eur J Entomol 109:21-28. doi:10.14411/ eje.2012.004

Caritat A, Gutiérrez E, Molinas M (2000) Influence of weather on corkring width. Tree Physiol 20:893-900

Carnicer J, Coll M, Ninyerola M, Pons X, Sánchez G, Peñuelas J (2011) Widespread crown condition decline, food web disruption, and amplified tree mortality with increased climate change-type drought. Proc Natl Acad Sci U S A 108:1474-8. doi:10.1073/pnas. 1010070108

Catry FX, Moreira F, Cardillo E, Pausas JG (2012) Post-fire management and restoration of Southern European forests. In: Moreira F F, Arianoutsou M, Corona P, De las Heras J (eds) Post-fire management and restoration of Southern European forests. Springer Netherlands, Dordrecht, pp 195-222

Catry FX, Moreira F, Branco M (2014) Fire-induced bark beetle attacks in Mediterranean cork oak forests : which factors drive host selection? Proceedings of the International conference on Mediterranean ecosystems - Medecos XIII. Olmué, Chile, p 2. doi:10.13140/ 2.1.2152.6722

Ceia RS, Ramos JA (2014) Birds as predators of cork and holm oak pests. Agrofor Syst. doi:10.1007/s10457-014-9749-7

Cerboneschi A (2005) Sensibilité de deux populations de Lymantria dispar L. au virus de la polyédrose nucléaire. IOBC/wprs Bull 28: 179-184
Chakali G, Attal-Bedreddine A, Ouzani H (2002) Les insectes ravageurs des chênes, Quercus suber et $Q$. ilex, en Algérie. IOBC/wprs Bull 25:93-100

Choi WIL (2011) Influence of global warming on forest coleopteran communities with special reference to ambrosia and bark beetles. J Asia Pac Entomol 14:227-231. doi:10.1016/j.aspen.2010.10.001

Cocco A, Cossu AQ, Erre P, Nieddu G, Luciano P (2010) Spatial analysis of gypsy moth populations in Sardinia using geostatistical and climate models. Agric For Entomol 12:417-426. doi:10.1111/j.14619563.2010.00488.x

Coley PD (1998) Possible effects of climate change on plant/herbivore interactions in moist tropical forests. Clim Change 39:455-472. doi: 10.1023/A: 1005307620024

Contarini M, Luciano P, Pilarska D, Pilarski P, Solter L, Huang W-F, Georgiev G (2013) Survey of pathogens and parasitoids in late instar Lymantria dispar larval populations in Sardinia, Italy. Bull Insectology 66:51-58

Correia B, Rodriguez JL, Valledor L, Almeida T, Santos C, Cañal MJ, Pinto G (2014) Analysis of the expression of putative heat-stress related genes in relation to thermotolerance of cork oak. J Plant Physiol 171:399-406. doi:10.1016/j.jplph.2013.12.004

Costa A, Madeira M, Plieninger T (2014) Cork oak woodlands patchiness: a signature of imminent deforestation? Appl Geogr 54:18-26. doi:10.1016/j.apgeog.2014.07.006

David TS, Henriques MO, Kurz-Besson C, Nunes J, Valente F, Vaz M, Pereira JS, Siegwolf R, Chaves MM, Gazarini LC, David JS (2007) Water-use strategies in two co-occurring Mediterranean evergreen oaks: surviving the summer drought. Tree Physiol 27:793-803. doi: 10.1093/treephys/27.6.793

Du Merle P (1999) Egg development and diapause: ecophysiological and genetic basis of phenological polymorphism and adaptation to varied host in the green oak tortrix, Tortrix viridana L. (Lepidoptera: Tortricidae). J Insect Physiol 45:599-611

Du Merle P, Attié M (1992) Coroebus undatus (Coleoptera: Buprestidae) sur chêne liège dans le Sud-Est de la France : estimation des dégâts, relations entre ceux-ci et certains facteurs du milieu. Ann des Sci For 49:571-588. doi:10.1051/forest:19920602

Duning JB, Stewart DJ, Daielson BJ, Noon BR, Root TL, Lamberson RH, Stevens EE (1995) Spatially explicit population models: current forms and future uses. Ecol Appl 5:3-11. doi:10.2307/1942045

El Antry S (1999) Biologie et dégâts de Cerambyx cerdo mirbecki Lucas (Coléoptère, Cerambycidae) en subéraie de la Mamora (Maroc). IOBC/wprs Bull 22:59-64

Evans H, Moraal LG, Pajares JA (2004) Biology, ecology and economic importance of Buprestidae and Cerambycidae. In: Lieutier F, Day $\mathrm{KR}$, Battisti A et al (eds) Bark and wood boring insects in living trees in Europe, a synthesis. Springer Netherlands, Dordrecht, pp $447-474$

Ezzine O, Hausmann A, Branco M, Mannai DY, Nouira S, Ben Jamâa ML (2014) Genetic patterns, host use and larval morphology in Tunisian populations of Orgyia trigotephras. Bull Insectology 67: 73-79

Ezzine O, Branco M, Villemant C, Schmidt S, Nouira S, Ben Jamâa ML (2015) Host use in Orgyia trigotephras (Erebidae, Lymantriinae) during outbreak: effects on larval performance and egg predation. Ann For Sci. doi:10.1007/s13595-015-0484-7

Feeny P (1970) Seasonal changes in oak leaf tannins and nutrients as a cause of spring feeding by winter moth caterpillars. Ecology 51: 565-581. doi:10.2307/1934037

Frago E, Guara M, Pujade-Villar J, Selfa J (2010) Winter feeding leads to a shifted phenology in the browntail moth Euproctis chrysorrhoea on the evergreen strawberry tree Arbutus unedo. Agric For Entomol 12:381-388. doi:10.1111/j.1461-9563.2010.00489.x

Fürstenau B, Rosell G, Guerrero A, Quero C (2012) Electrophysiological and behavioral responses of the black-banded oak borer, Coroebus 
florentinus, to conspecific and host-plant volatiles. J Chem Ecol 38: 378-388. doi:10.1007/s10886-012-0110-1

Fürstenau B, Quero C, Riba JM, Rosell G, Guerrero A (2014) Field trapping of the flathead oak borer Coroebus undatus (Coleoptera: Buprestidae) with different traps and volatile lures. Insect Sci 22: 139-149. doi:10.1111/1744-7917.12138

Gallardo A, Jiménez A, Antonietty CA, Villagrán M, Ocete ME, Soria FJ (2012) Forecasting infestation by Coraebus undatus (Coleoptera, Buprestidae) in cork oak forests. Int J Pest Manag 58:275-280. doi:10.1080/09670874.2012.698765

Gilioli G, Luciano P, Serra G (1999) Contributo allo studio di un metodo di campionamento dell'abbondanza delle ovideposizioni di Tortrix viridana L. (Lepidoptera Tortricidae). Frustula Entomol 185-190

González E, Núñez L, Lencina J, Gallego D (2013) Evaluación de los niveles de infestación y medidas de control de Cerambyx cerdo (Linnaeus, 1758) en Mallorca (Islas Baleares). Prooceedings of the $6^{\circ}$ Congreso Forestal Español. Sociedad Española de Ciencias Forestales, Pontevedra

Grant OM, Tronina L, Ramalho JC, Besson CK, Lobo-do-Vale R, Pereira JS, Jones HG, Chaves MM (2010) The impact of drought on leaf physiology of Quercus suber L. trees: comparison of an extreme drought event with chronic rainfall reduction. J Exp Bot 61:436171. doi:10.1093/jxb/erq239

Hajek AE, Tobin PC (2010) Micro-managing arthropod invasions: eradication and control of invasive arthropods with microbes. Biol Invasions 12:2895-2912. doi:10.1007/s10530-010-9735-6

Hance T, van Baaren J, Vernon P, Boivin G (2007) Impact of extreme temperatures on parasitoids in a climate change perspective. Annu Rev Entomol 52:107-126. doi:10.1146/annurev.ento.52.110405. 091333

Henriques J, Inácio ML, Sousa E (2006) Ambrosia fungi in the insectfungi symbiosis in relation to cork oak decline. Rev Iberoam Micol 23:185-188

Henriques J, Inácio ML, Pires S, Sousa E (2010) Platypus cylindrus Fab. (Coleoptera: Platypodidae) control strategies. IOBC/wprs Bull 57: 103-106. doi:10.1017/CBO9781107415324.004

Huberty AF, Denno RF (2004) Plant water stress and its consequences for herbivorous insects: a new synthesis. Ecology 85:1383-1398

Ibarra N, Lastanao C, Gil-Pelegrín E, Martín-Bernal E (2001) Kermes vermilio Planchon, parásito de quercíneas en Aragón. Primeras observaciones. Proceedings of the III Congreso Forestal Español. Granada

Inácio ML, Henriques J, Sousa E (2011) Contribution symbiotic fungi to cork oak colonization by Platypus cylindrus (Coleoptera: Platypodidae). Silva Lusit 19:89-99

Inbar M, Doostdar H, Mayer RT (2001) Suitability of stressed and vigorous plants to various insect herbivores. Oikos 94:228-235. doi:10. 1034/j.1600-0706.2001.940203.x

IPCC (2014) Climate change 2014: Synthesis report. Contribution of working groups I, II and III to the fifth assessment report of the intergovernmental panel on climate change, IPCC. Geneva, Switzerland

Ivashov AV, Boyko GE, Simchuk AP (2002) The role of host plant phenology in the development of the oak leafroller moth, Tortrix viridana L. (Lepidoptera: Tortricidae). For Ecol Manage 157:7-14. doi:10.1016/S0378-1127(00)00652-6

Jacobson M, Beroza M, Jones WA (1960) Isolation, identification, and synthesis of the sex attractant of gypsy moth. Science 132:10111012. doi:10.1126/science.132.3433.1011

Jactel H, Nicoll BC, Branco M, Gonzalez-Olabarria RJ, Grodzki W, Långström B, Moreira F, Netherer S, Orazio C, Piou D, Santos H, Schelhaas MJ, Tojic K, Vodde F (2009) The influences of forest stand management on biotic and abiotic risks of damage. Ann For Sci 66:701-701. doi:10.1051/forest/2009054

Jiménez A, Gallardo A, Antonietty CA, Villagrán M, Ocete ME, Soria FJ (2012) Distribution of Coraebus undatus (Coleoptera: Buprestidae) in cork oak forests of southern Spain. Int J Pest Manag 58:281-288. doi:10.1080/09670874.2012.700493

Kapeller S (2009) Modelling of population dynamics of the green oak leaf roller (Tortrix viridana) within oak-populations. Thesis, University of Vienna

Klapwijk MJ, Ayres MP, Battisti A, Larsson S (2012) Assessing the impact of climate change on groundwater quality in Turkey. In: Barbosa P, Letourneau DK, Agrawal AA (eds) Insect outbreaks revisited, first edit. Blackwell Publishing Ltd, pp 429-450

Koricheva J, Larsson S, Haukioja E (1998) Insect performance on experimentally stressed woody plants: a meta-analysis. Annu Rev Entomol 43:195-216. doi:10.1146/annurev.ento.43.1.195

Kula E, Pešlová A, Martinek P, Mazal P (2013) The development of caterpillars of gypsy moth (Lymantria dispar L.) feeding on food affected by nitrogen. J For Soc Croat 137:51-59

Kumar PV, Bindi M, Crisci A, Maracchi G (2005) Detection of variations in air temperature at different time scales during the period 1889 1998 at Firenze, Italy. Clim Change 72:123-150. doi:10.1007/ s10584-005-5970-8

Kurz-Besson C, Otieno D, Lobo-do-Vale R, Siegwolf R, Schmidt M, Herd A, Nogueira C, David TS, David JS, Tenhunen J, Pereira JS, Chaves M (2006) Hydraulic lift in cork oak trees in a savannah-type Mediterranean ecosystem and its contribution to the local water balance. Plant Soil 282:361-378. doi:10.1007/s11104-006-0005-4

Liebhold AM, Elkinton JS, Zhou C, Hohn ME, Rossi RE, Boettner GH, Boettner CW, Burnham C, McManus ML (1995) Regional correlation of gypsy moth (Lepidoptera: Lymantriidae) defoliation with counts of egg masses, pupae, and male moths. Environ Entomol 24:193-203. doi:10.1093/ee/24.2.193

Loi A, Luciano P, Gilioli G, Bodini A (2012) Lasius brunneus (Formicidae Formicinae) and Stomaphis quercus (Aphidoidea Aphididae): trophobionts harmful to cork oak forests in Sardinia (Italy). Redia 95:21-29

López-Pantoja G, Dominguez L, Sánchez-Osorio I (2011) Analysis of Prinobius myardi Mulsant population dynamics in a Mediterranean cork oak stand. Ann la Société Entomol Fr 47:260 268. doi:10.1080/00379271.2011.10697717

Luciano P, Lentini A (2012) Ten years of microbiological control program against lepidopterous defoliators in Sardinian cork oak forests. IOBC/wprs Bull 76:175-178

Luciano P, Prota R (1995) Insect pests in Sardinian cork-oak forests. IOBC/wprs Bull 18:1-7

Luciano P, Lentini A, Dettori C, Solinas V, Passino GS (1999) Gypsy moth development on foliage of several oaks in Sardinia. IOBC/wprs Bull 22:89-94

Luisi N, Lerario P, Vannini A (1993) Recent advances in studies on oak decline. Proceedings of an international congress. Italy, September 13-18, 1992. Università degli Studi di Bari, Selva Di Fasano (Brindisi)

Luque J, Pera J, Parladé J (2008) Evaluation of fungicides for the control of Botryosphaeria corticola on cork oak in Catalonia (NE Spain). For Pathol 38:147-155. doi:10.1111/j.1439-0329.2007.00526.x

Magnoler A, Cambini A (1970) Effects of artificial defoliation on the growth of cork oak. For Sci 16:364-366

Magri D, Fineschi S, Bellarosa R, Buonamici A, Sebastiani F, Schirone B, Simeone MC, Vendramin GG (2007) The distribution of Quercus suber chloroplast haplotypes matches the palaeogeographical history of the Western Mediterranean. Mol Ecol 16:5259-66. doi:10. 1111/j.1365-294X.2007.03587.x

Mannai Y, Ben Jamâa ML, Mnara S, Selmi H, Nouira S (2010) Biology of Tortrix viridana (Lep., Tortricidae) in cork oak forests of NorthWest Tunisia. IOBC/wprs Bull 57:153-160

Marques JF, Wang H-L, Svensson GP, Frago E, Anderbrant O (2014) Genetic divergence and evidence for sympatric host-races in the highly polyphagous brown tail moth, Euproctis chrysorrhoea 
(Lepidoptera: Erebidae). Evol Ecol 28:829-848. doi:10.1007/ s10682-014-9701-3

Martin J-C, Villemant C, Mazet R (2002) Utilisation de Bacillus thuringiensis kurstaki 3a-3b dans la lutte contre le bombyx disparate et problèmes posés par les migrations de chenilles. IOBC/wprs Bull 25:115-122

Martín J, Cabezas J, Buyolo T, Patón D (2005) The relationship between Cerambyx spp. damage and subsequent Biscogniauxia mediterranum infection on Quercus suber forests. For Ecol Manage 216:166-174. doi:10.1016/j.foreco.2005.05.027

Mattson WJ, Haack RA (1987) Role of drought in outbreaks of planteating insects. Drought's physiological effects on plants can predict its influence on insect populations. Bioscience 37:110-118

Michel A, Seidling W, Lorenz M, Becher G (2014) Forest Condition in Europe: 2013 technical report of ICP forests. Report under the UNECE convention on long-range transboundary air pollution. http://literatur.ti.bund.de/digbib_extern/dn053404.pdf kostenfrei

Mnara S, Ben Jamaâ ML, Nouira S (2005) Bilan des observations sur Lymantria dispar (L.) en phase de latence en Tunisie. IOBC/wprs Bull 28:147-154

Moraal LG, Jagers op Akkerhuis GAJM (2011) Changing patterns in insect pests on trees in the Netherlands since 1946 in relation to human induced habitat changes and climate factors - an analysis of historical data. For Ecol Manage 261:50-61. doi:10.1016/j. foreco.2010.09.024

Muzika RM, Liebhold AM, Twery MJ (2000) Dynamics of twolined chestnut borer Agrilus bilineatus as influenced by defoliation and selection thinning. Agric For Entomol 2:283-289. doi:10.1046/j. 1461-9563.2000.00077.x

Nealis VG, Roden PM, Ortiz DA (1999) Natural mortality of the gypsy moth along a gradient of infestation. Can Entomol 131:507-519. doi:10.4039/Ent131507-4

Nogueira C (1968) Pragas dos montados de sobro e azinho. Rev Agronómica 5:66-74

Ockendon N, Baker DJ, Carr JA, White EC, Almond REA, Amano T, Bertram E, Bradbury RB, Bradley C, Butchart SHM, Doswald N, Foden W, Gill DJC, Green RE, Sutherland WJ, Tanner EVJ, PearceHiggins JW (2014) Mechanisms underpinning climatic impacts on natural populations: altered species interactions are more important than direct effects. Glob Chang Biol 20:2221-2229. doi:10.1111/ gcb.12559

Ouakid ML, Farine J-P, Soltani N (2005) Effets des extraits de plantes associées au chêne-liège sur l'attraction en enceinte des chenilles de Lymantria dispar. IOBC/wprs Bull 28:171-178

Pereira P, Godinho C, Roque I, Marques A, Branco M, Rabaça JE (2012) Time to rethink the management intensity in a Mediterranean oak woodland: the response of insectivorous birds and leaf-chewing defoliators as key groups in the forest ecosystem. Ann For Sci 71:2532. doi:10.1007/s13595-012-0227-y

Petrucci C, Marchi G, Panzavolta T, Tiberi R, Filindassi M, Ruiu L (2012) Persistence of Bacillus thuringiensis subsp. kurstaki. IOBC/wprs Bull 76:179-183

Pinto CA, Henriques MO, Figueiredo JP, David JS, Abreu FG, Pereira JS, Correia I, David TS (2011) Phenology and growth dynamics in Mediterranean evergreen oaks: effects of environmental conditions and water relations. For Ecol Manage 262:500-508. doi:10.1016/j. foreco.2011.04.018

Pujade-Villar J, Grami M, Ben Jamâa ML (2010) The gall wasp Plagiotrochus amenti potentially dangerous for the cork oak found for the first time in Tunisia. Tunis J Plant Prot 5:223-228

Roden DB, Mattson WJ (2008) Rapid induced resistance and host species effects on gypsy moth, Lymantria dispar (L.): implications for outbreaks on three tree species in the boreal forest. For Ecol Manage 255:1868-1873. doi:10.1016/j.foreco.2007.12.008

Sallé A, Nageleisen L, Lieutier F (2014) Bark and wood boring insects involved in oak declines in Europe: current knowledge and future prospects in a context of climate change. For Ecol Manage 328:7993. doi: $10.1016 /$ j.foreco.2014.05.027

Sánchez-Osorio I, Tapias R, Domínguez I, López G (2007) Characterization of the electroantennographic response by Cerambyx welensii Küster and Prinobius germari Germar (Coleoptera: Cerambycidae) to olfactory stimuli. Forest Syst 16: 95-106

Sánchez-Osorio I, Tapias R, Domínguez L (2009) Variabilidad intraespecífica de la respuesta electroantenográfica en Cerambyx welensii Küster (Coleoptera, Cerambycidae). Influencia de factores anatómicos, fisiológicos y experimentales. Forest Syst 18:140-151

Sánchez-Osorio I, Domínguez L, López-Pantoja G, Tapias R (2015a) Antennal response of Prinobius myardi to synthetic tree volatiles. Silva Fenn 49:1-8. doi:10.14214/sf.1305

Sánchez-Osorio I, López-Pantoja G, Paramio AM, Lencina JL, Gallego D, Domínguez L (2015b) Field attraction of Cerambyx welensii to fermentation odors and host monoterpenes. J Pest Sci. doi:10.1007/ s10340-015-0654-2

Schafellner C, Marktl RC, Nussbaumer C, Schopf A (2004) Parasitisminduced effects of Glyptapanteles liparidis (Hym., Braconidae) on the juvenile hormone titer of its host, Lymantria dispar: the role of the parasitoid larvae. J Insect Physiol 50:1181-1189. doi:10.1016/j. jinsphys.2004.10.011

Schafellner C, Krämer W, Schopf A (2005) Three trophic level interaction: the influence of host plants on the performance of gypsy moth (Lymantria dispar) and its parasitoid, Glyptapanteles liparidis (Hymenoptera, Braconidae). IOBC/wprs Bull 28:193-200

Schroeder H, Tiberi R (2014) Ecological interactions of the host-insect system Quercus robur and Tortrix viridana. In: Fenning T (ed) Challenges and opportunities for the world's forests in the 21st century. Springer Netherlands, Dordrecht, pp 739-765

Sechi C, Ruiu P, Franceschini A, Corda P (2002) Nouvelles recherches sur l'extension des phénomènes de dépérissement dans les subéraies de Sardaigne. IOBC/wprs Bull 25:5-12

Sedda L, Delogu G, Dettori S (2011) Forty-four years of land use changes in a Sardinian cork oak agro-silvopastoral system: a qualitative analysis. Open For Sci J 4:57-66

Serra G, Lentini A (2012) Egg development and diapause in Sardinian populations of Tortrix viridana L. IOBC/wprs Bull 76:197-200

Serrão M (2002) Damage evolution and control of Lymantria dispar L. in a cork oak forest of southern Portugal. IOBC/wprs Bull 25:109-114

Simchuk APV, Ivashov A, Companiytsev VA (1999) Genetic patterns as possible factors causing population cycles in oak leafroller moth, Tortrix viridana L. For Ecol Manage 113:35-49. doi:10.1016/ S0378-1127(98)00340-5

Singer MC, Parmesan C (2010) Phenological asynchrony between herbivorous insects and their hosts: signal of climate change or preexisting adaptive strategy? Philos Trans R Soc B Biol Sci 365: 3161-3176. doi:10.1098/rstb.2010.0144

Skelly DK, Joseph LN, Possingham HP, Freidenburg LK, Farrugia TJ, Kinnison MT, Hendry AP (2007) Evolutionary responses to climate change. Conserv Biol 21:1353-1355. doi:10.1111/j.1523-1739. 2007.00764.x

Skuhravá M, Skuhravý V, Blasco-Zumeta J, Pujade-Villar J (2006) Gall midges (Diptera: Cecidomyiidae) of the Iberian Peninsula. Zoogeographical analysis of the gall midge fauna. Bol Asoc Esp Entomol 30:93-159

Sousa EMR, Inácio ML (2005) New aspects of Platypus cylindrus Fab. (Coleoptera : Platypodidae) life history on cork oak stands in Portugal. Entomological Research in Mediterranean Forest Ecosystems. pp 147-168

Sousa EMR, Kadiri Z (2005) Le déclenchement des perturbations physiologiques des peuplements de chêne-liège: une synthèse des relations agent/hôte. IOBC/wprs Bull 28:9-16

Stange EE, Ayres MP (2010) Climate change impacts: insects. Encyclopedia of life sciences. Wiley, Chichester 
Stireman JO, Dyer LA, Janzen DH, Singer MS, Lill JT, Marquis RJ, Ricklefs RE, Gentry GL, Hallwachs W, Coley PD, Barone JA, Greeney HF, Connahs H, Barbosa P, Morais HC, Diniz IR (2005) Climatic unpredictability and parasitism of caterpillars: implications of global warming. Proc Natl Acad Sci U S A 102:17384-17387. doi:10.1073/pnas.0508839102

Thomas F (2008) Recent advances in cause-effect research on oak decline in Europe. CAB Rev Perspect Agric Vet Sci Nutr Nat Resour 3:112. doi:10.1079/PAVSNNR20083037

Thomas FM, Blank R, Hartmann G (2002) Abiotic and biotic factors and their interactions as causes of oak decline in Central Europe. For Pathol 32:277-307. doi:10.1046/j.1439-0329.2002.00291.x

Thorpe K, Reardon R, Tcheslavskaia K, Leonard D, Mastro V (2006) A review of the use of mating disruption to manage gypsy moth, Lymantria dispar (L.). Forest Health Technology Enterprise Team, Morgantown

Tiberi R, Covassi M (1994) Interventi integrati di controllo dei fitofagi forestali. Proceedings of the XVII Congresso nazionale Italiano di Entomologia. Arti Grafiche Friulane, Udine, pp 763-766

Tiberi R, Covassi M, Roversi PF (1988) La tecnica della confusione contro Rhyacionia bouliana (Den. et Schiff.) in giovani pinete dell'Italia centrale (Lepidoptera, Tortricidae). Redia 71:355-368

Tiberi R, Prota R, Masutti L (1993) Esigenze, prospettive e proposte di nuovi criteri di intervento per il controllo dei lepidotteri defoliatori delle foreste. Proceedings of the Convegno Piante Forestali. Istituto Sperimentale di Patologia Vegetale, Roma, Florence, pp 19-34

Tiberi R, Ragazzi A, Marianelli L, Peverieri Sabbatini P, Roversi PF (2002) Insects and fungi involved in oak decline in Italy. IOBC/wprs Bull 25:67-74

Torres-Vila LM, Sanchez-González Á, Ponce-Escudero F, MartínVertedor D, Ferrero-García JJ (2012) Assessing mass trapping efficiency and population density of Cerambyx welensii Küster by mark-recapture in dehesa open woodlands. Eur J For Res 131: 1103-1116. doi:10.1007/s10342-011-0579-0

Torres-Vila LM, Sánchez-González Á, Merino-Martínez J, PonceEscudero F, Conejo-Rodríguez Y, Martín-Vertedor D, FerreroGarcía JJ (2013) Mark-recapture of Cerambyx welensii in dehesa woodlands: dispersal behaviour, population density, and mass trapping efficiency with low trap densities. Entomol Exp Appl 149:273281. doi:10.1111/eea.12133

Vaz M, Cochard H, Gazarini L, Grac J, Chaves MM, Pereira JS (2012) Cork oak (Quercus suber L.) seedlings acclimate to elevated $\mathrm{CO}^{2}$ and water stress: photosynthesis, growth, wood anatomy and hydraulic conductivity. Trees 26:1145-1157. doi:10.1007/s00468012-0691-x

Verdinelli M, Sanna-Passino G (2003) Development and feeding efficiency of Malacosoma neustrium larvae reared with Quercus spp. leaves. Ann Appl Biol 143:161-167. doi:10.1111/j.1744-7348. 2003.tb00282.x

Verdinelli M, Luciano P, Serra G (2002) Frequency distribution of Malacosoma neustria (L.) egg masses and nests in cork oak forests. IOBC/wprs Bull 25:151-154

Verdinelli M, Loi A, Luciano P (2012) Ant species noxious to cork oak in Sardinia. IOBC/wprs Bull 76:249-252

Vericat P, Piqué M, Serrada R (2012) Gestión adaptativa al cambio global en masas de Quercus mediterráneos. Centre Tecnològic Forestal de Catalunya, Solsona (Lleida)

Villagrán M, Jiménez A, Soria FJ, Ocete ME (2002) Muestreo de Dryomia lichtensteini (F.Lw.) (Diptera: Cecidomyiidae) en alcornoque. Bol San Veg Plagas 28:127-132

Villemant C (2005) La gradation 2000-2003 du bombyx disparate en Corse: échantillonnage simplifié des pontes et étendue des défoliations. IOBC/wprs Bull 28:155-162

Villemant C, Fraval A (1993a) Les insectes du chêne-liège. Insectes 88: $13-16$

Villemant C, Fraval A (1993b) La faune entomologique du chêne-liège en forêt de la Mamora (Maroc). Ecol Mediterr XIX:89-98

Villemant C, Fraval A (1999) Les gradations de Lymantria dispar en Europe et en Afrique du Nord. IOBC/wprs Bull 22:71-79

Werno J, Lamy M (1994) Daily cycles for emission of urticating hairs from the pine processionary caterpillar (Thaumetopoea pityocampa S.) and the brown tail moth (Euproctis chrysorrhoea L.) (Lepidoptera) in laboratory conditions. Aerobiologia (Bologna) 10: 147-151 